\begin{tabular}{|l|c|}
\hline \multicolumn{2}{|c|}{ Toppan Best-set Premedia Limited } \\
\hline Journal Code: BJPI & Proofreader: Mony \\
\hline Article No: BJPI12003 & Delivery date: 28 Nov 2012 \\
\hline Page Extent: 24 & \\
\hline
\end{tabular}

\title{
Public Deliberation, Networks Analysis and the Political Integration of Muslims in Britain
}

\section{Manlio Cinalli and Ian O'Flynn}

\author{
Research Highlights and Abstract \\ This article
}

- Is one of the first papers to bring deliberative theory and network theory together.

- Maps 'who is talking to whom' in the field of ethnic relations in Britain.

- Argues that, while Muslim actors do not necessarily couch their claims in general terms, they are well integrated nevertheless.

In this article, we examine the assumption that, insofar as actors deliberate well, political integration will follow. We do so specifically with respect to the political integration of Muslims in the field of ethnic relations in Britain, using data retrieved from two quality British broadsheets. Our approach has two components. First, we consider the quality of the deliberative interventions actors make, comparing Muslim actors with other actors. Second, we use measures drawn from network analysis to assess the level of political integration as indicated by the ties that those deliberative interventions forge. Our findings show that the link between how Muslim actors deliberate and their political integration in the field is more complex that one might assume. Although Muslims do not deliberate as well as normative deliberative theory says they should, empirically they are politically integrated, having forged diverse relationships that avoid the danger of polarisation.

Keywords: deliberative democracy; network analysis; political integration; British Muslims

In recent years, the British government has become increasingly concerned about the lack of political integration of Muslims living in Britain. This concern, which can be viewed as part of a broader British concern with ethnic relations generally, is shared by a great many actors besides government, including civil society organisations, trade unions, the media and ordinary individuals. And of course it is also shared by some of those who define themselves in the first instance as 'Muslim'. ${ }^{1}$ This article is not about the reasons why the political integration of Muslims has become such a salient topic in Britain. Rather, its aim is to offer a new perspective on that topic by considering the relationship between public deliberation and political integration.

There are many views on what public deliberation ideally ought to involve (cf. Cohen 1989; Gutmann and Thompson 1996; Habermas 1996; Dryzek 2000). Yet all deliberative theorists agree that important decisions of law and policy should turn not on the force of numbers but on what Jürgen Habermas calls 'the force of the 
better argument' (Habermas 1984, 25). As such, we must pay attention to the views of other actors, listen respectfully to what they have to say, and develop our views and opinions in ways that make them responsive to theirs. Insofar as actors live up to this normative ideal, deliberative theorists claim that certain normatively desirable consequences will follow. Some of those consequences are central to traditional understandings of political integration-inter alia, greater levels of engagement in public affairs, trust in government and faith in the democratic process, a strong sense of political self-efficacy, increased levels of information seeking and political participation (Fishkin 1995, 2009; Mendelberg 2002; Delli Carpini et al. 2004; Searing et al. 2007).

Our concern is to examine the extent to which public deliberation in Britain is linked to desirable consequences of this sort, focusing in particular on the political role and position of Muslims in the public sphere. For us, political integration is not just engagement in public affairs, trust in government, self-efficacy, and so forth, but consists especially of durable ties or relationships forged by and among different actors. Those relationships can be created or sustained in different ways or through different types of activity. On the face of it, one might naturally assume that public deliberation is one such activity (see Habermas 1987). Yet as Diana Mutz argues, this assumption may or may not be well founded. As she argues, 'the tests of deliberative theory offered to date typically do not develop well-specified explanations for the relationships between deliberation and its many proposed benefits' (Mutz 2008, 525). While deliberative theorists tend to assume that as long as actors deliberate well, political integration will follow, this assumption has not been systematically tested. We use network analysis to see whether the field of ethnic relations in Britain is characterised by durable ties and relationships between diverse actors and, in particular, to assess the specific contribution made by Muslims to the forging of those relationships. In sum, our aim in taking this approach is to check whether a relationship actually exists between public deliberation and political integration and, if so, to offer an assessment of the character of that relationship.

In the first section, we define 'public deliberation' in terms of three basic requirements or normative components. We argue, however, that when it comes to operationalising those requirements for the purposes of empirical analysis, particular attention must be paid to the actual context in which they are to apply. In the second section, we define what we mean by 'political integration'. Whereas contemporary scholarship treats political engagement as the key indicator of political integration (e.g. van Deth et al. 2007; Morales and Giugni 2011), we stress the mutual ties or relationships that that engagement involves. In making this case, we distinguish between ties of support and dissent and emphasise the importance of considering whether the prevailing pattern of support and dissent maps onto deep divisions in the field. In the third section, we turn to questions of design and data. Our analysis has two main components- the first component involves evaluating 'deliberative interventions' in the field of ethnic relations in Britain, while the second component examines the relational dimension of this field. Since our data is drawn from newspapers, we also consider some attendant difficulties. In the fourth section, we present our findings, while in the fifth we turn to our discussion. 
Before proceeding, two points are worth noting. First, as we have said, the aim of this article is map the relationship between public deliberation and political integration in the field of ethnic relations in Britain. But since the relationship between public deliberation and political integration may look very different in, for example, Britain or France, we cannot safely generalise from our results. That said, our approach is not specific to the field of ethnic relations or to Britain; it could, conceivably, be applied to an indeterminate number of policy fields and countries. Secondly, as we have also indicated, deliberative democrats assume that if actors deliberate well, political integration will follow. Yet while this treats political integration as an outcome of public deliberation, one might just as easily suppose that political integration is a pre-requisite of public deliberation. Public deliberation probably does require some threshold level of political integration. But it may be that that threshold does not need to be very high for public deliberation to commence. Once it has commenced, it may well lead to greater levels of political integration, just as deliberative democrats suppose.

\section{Deliberation}

Some deliberative theorists tend to focus on the policy domain of institutions and political elites (e.g. Bessette 1994; Habermas 1996; Elster 1998; Uhr 1998) whereas others tend to focus on the broader public domain of individuals and civil society (e.g. Mansbridge 1980, 1999; Fung 2003; Jacobs et al. 2009; Smith 2009). Yet in whichever domain, the general guiding assumption is that proposed laws and policies should be assessed on their merits-they should be based on the balance of evidence and not merely on the balance of voting power.

That said, moving from the policy domain to the broader public sphere has required deliberative theorists to relax some standards and to introduce certain others. For example, some deliberative theorists claim that arguments for or against public policies should be couched in the language of democratic principles or other widely shared political considerations (e.g. Cohen 1996, 99-100; Gutmann and Thompson 1996, 3-4; Rawls 1996, 100-101). Yet this claim has led critics to argue that deliberative theory is biased against those who do not have access to a sophisticated political vocabulary and who might therefore struggle to express themselves in such terms (e.g. Sanders 1997; Williams 2000; Young 2000). Hence, these critics argue that instead of necessarily having to appeal to, for example, a principle of equality, ordinary people might instead simply describe events from their life histories (but see Dryzek 2000, 68-69).

Shifting from one domain to another also has implications for those interested in measuring deliberation empirically. A good case in point here is the discourse quality index' (DQI), a quantitative measurement tool for assessing public deliberation (Steenbergen et al. 2003). Normatively, the DQI is expressly grounded in Habermas's discourse ethics (Habermas 1991). In the ideal case, deliberation will be open, reasoned, respectful and authentic; it will also be marked by a concern for the common good and will aim at consensus. Yet the coding categories that are meant to measure the degree to which these attributes are present in any given instance of deliberation are as much a reflection of the parliamentary context to which the 
DQI was originally intended to apply as of the normative theory from which they were originally derived. For instance, the DQI seeks to measure the openness of a parliamentary debate in terms of the degree to which a speaker is interrupted by some other parliamentarian (Steenbergen et al. 2003, 27). Yet while one could also envision using this measure to assess the quality of deliberation on display in, for example, the context of a deliberative poll (Fishkin and Luskin 2005) or other such 'mini-public', it might not so easily apply to deliberation in the broader public sphere. This latter contains a plurality of actors who do not necessarily deliberate face-to-face. And since they may not have deliberated face-to-face, the degree to which one speaker is interrupted by another speaker is obviously not a telling measure.

In any large democracy, it is impossible for everyone to deliberate together in a single arena. Consequently, actors must rely to a considerable extent on the mass media to make information available to them and to debate the pros and cons of different policy choices on their behalf. There is, in fact, a growing body of research that seeks to assess the quality of deliberation on display in the media, and especially in newspapers (e.g. Page 1996; Ferree et al. 2002; Wessler 2008; Dolezal et al. 2010). Yet in order to measure claims made in the media, appropriate codes need to be devised-and indeed different codes may be required for different media (cf. Mutz 2008, 527).

When it comes to devising appropriate codes, much will therefore depend on the particular locus to which those codes are to apply; there is no 'one size fits all' measurement instrument on which empirically-minded deliberative theorists can rely. Researchers must also be explicit about their guiding normative assumptions and the arguments for them. Our normative starting point is the fact that, in any modern pluralistic society, different actors will tend to see the world in different ways. This variation is perfectly natural. But it carries with it certain implications for how we ought to relate to one another as political equals. Recognising others as equals in political argument means recognising that those others can have reasons to hold their views as firmly as we hold ours. Hence, if we do not make a serious effort to deliberate with them and try to offer arguments that they could in principle accept, we fail to respect their standing as political equals (Cohen 1996, 101; Rawls 1996, 54-58).

This understanding of political equality can justify three of the more commonly posited requirements (or necessary conditions) of public deliberation. Any serious attempt to measure public deliberation must consider whether actors (i) couch their interventions in language that is acceptable to others, (ii) provide a valid supporting argument and (iii) show concern for the general interest. The thinking behind this last condition is this: since policy decisions are mutually binding, they should be mutually justifiable. Hence, actors should be prepared to appeal to the general interest (Gutmann and Thompson 1996). This is not to say that particular interests are irrelevant to the policy process. But ultimately policy decisions cannot be justified on such grounds alone. In short, deliberative democracy requires actors to take a broader view of public issues than merely consulting their own interests in them (O'Flynn 2010; cf. Mansbridge 2010). 


\section{Political Integration}

Political integration is often understood in terms of political interest, electoral participation and trust in both institutions and political elites (e.g. Verba et al. 1995; Berger et al. 2004; Jacobs et al. 2004; van Deth et al. 2007; Morales and Giugni 2011). This understanding of political integration places a great deal of emphasis on active engagement in the political life of the country in which an actor lives (Berger et al. 2004; Jacobs et al. 2004). More generally, for scholars who share this understanding, active engagement is treated as vital to democracy because it helps hold government to account while also fostering the sorts of civic disposition upon which a healthy demos depends. In this latter vein, John Stuart Mill famously argued that political engagement could contribute to the raising of the moral character: Each citizen 'is called upon, while so engaged, to weigh interests not his own; to be guided, in case of conflicting claims, by another rule than his private partialities; to apply, at every turn, principles and maxims which have for their reason of existence the common good' (Mill [1861] 1991, 255).

Our conceptualisation of political integration gives the same centrality to the idea of political engagement. However, we give a 'relational twist' to this idea by considering actors to be politically integrated when they have forged extensive ties with other actors across the polity. These ties enable actors to exchange flows of information, reinforce overarching values and capitalise on opportunities for intervening in the policy process (e.g. Lin 2001; Diani and McAdam 2003; Cinalli 2004 and 2007). In so doing, we draw upon recent social science research on relational attributes and in particular on studies of social capital that have highlighted how actors access and make use of trust and resources through their ties, both at the individual level (Lin 1999 and 2001) and at the group level (Bourdieu 1986; Coleman 1990; Putnam 1993 and 2000). Clearly, there is scope for applying lessons from the study of social capital to issues of ethnic and religious integration: for example, recent scholarship has shown that participation in political elections can be explained by reference to the structure of ethnic communities as reflected in networks of ethnic organisations (Fennema and Tillie 1999).

In a further advancement of previous studies, we focus not only on ties of support, as an indicator of the exchange of values, resources, trust etc., but also on ties of dissent. The analysis of patterns of support is useful to detect underlying structures of mutual alliance, while the analysis of patterns of dissent is useful to detect underlying structures of mutual opposition, that is, structures that are less favourable to the exchange of values, resources, trust etc. At the same time, we examine systematically not only ties which Muslims forge with civil society actors in the public domain but also ties which Muslims forge with institutions and political elites in the policy domain. While this latter type of 'vertical' network (Cinalli 2004) has thus far received little scholarly attention, here it is treated as crucial for reaching a systematic appraisal of Muslims' political integration.

In sum, Muslims may or may not build ties of support and/or dissent with other actors across the public and policy domains, so our analysis seeks to (i) evaluate the shape and intensity of these interactions and (ii) to ass the extent to which the prevailing pattern of support and dissent maps onto deep divisions in the field. 
Along the first dimension, the main goal is to check whether Muslim actors engage extensively with other actors in the field-evidence showing the extensive prevalence of ties of support over dissent would serve as a first indication of political integration in the field. But even if Muslims engage extensively both with civil society actors and with policy makers, we still need to check whether the way in which they engage occurs along some deep hidden cleavage in the field. Crucially, the presence of unconnected blocks of actors may reveal deep divisions and processes of polarisation at work in the field, with actors tending to engage only with 'like-minded' others. This is a crucial strand of our research, since 'group polarisation' is viewed with utmost concern in deliberative theory.

Deliberative theorists worry that if a group of people from the same background (demographic, attitudinal etc.) meet to discuss an issue, their deliberations may conform to what Cass Sunstein calls 'the law of group polarisation' (Sunstein 2002). That law refers to a statistical regularity which allows us to predict that when like-minded people meet to discuss an issue of importance to them, they will move toward a more extreme point in the direction indicated by the median point of their prior views and opinions. Of course, the mere fact of moving in a more extreme direction is neither good nor bad in itself. But if people only engage in political discussions with 'like-minded others', the chances are that they will become more entrenched in their views and hence less responsive to the views of others. Insofar as this occurs, integration may be hindered rather than facilitated.

As Dennis Thompson argues, the assumption that like-mindedness encourages group polarisation needs to be systematically tested (Thompson 2008, 502). We take up this challenge below. For now, though, the point to stress is that our analysis proceeds on basis that (i) the salience of support and dissent and (ii) the salience of deep divisions can be combined into an overall measure of political integration. Accordingly, the political integration of Muslims is well developed across both the public and the policy domains when, just like other actors in the field, their engagement is characterised by high intensity of support over dissent as well as low saliency of cleavages. By contrast, high intensity of dissent over support combined with high saliency of cleavages indicates a correspondingly low level of political integration.

\section{Design and Data}

As indicated above, the overall design of the argument of this article has two main components. The first component involves evaluating deliberative interventions in the field of ethnic relations in Britain, and specifically those interventions that allow us to assess how Muslim actors deliberate in comparison to other actors. Specifically, we code any intervention pertaining to Muslim and other ethnic or religious minority actors, as well as all interventions made by Muslim and other ethnic or religious minority actors themselves. The second component examines the relational dimension of the field, which extends from the core policy domain of governmental institutions and political elites to the public domain of civil society organisations. The aim of this second component is to study the networks and 
channels of political engagement between Muslims and other actors. Together, the two components allow us to appraise the purported link between public deliberation and political integration.

Methodologically, the first component of our analysis draws upon 'claims making analysis' (Koopmans and Statham 1999; Giugni and Passy 2004) to assess the content of newspaper articles (we discuss some of the difficulties and dangers, but also some of the advantages, in coding newspapers below). This method has proved to be useful in analysing the roles and positions of different actors within national public spheres, extending the more traditional method of 'protest event analysis' in studies of contentious politics (Tilly et al. 1975; Kriesi et al. 1995; Tarrow 1998). In our approach, claims making analysis is itself extended so as to go beyond an assessment of the public sphere in terms of its factual articulations in order to provide an evaluation of the quality of the deliberative interventions actors make. For us, a 'deliberative intervention' is a verbal statement made by an actor in the public sphere that rests upon a variable articulation of an argument in relation to the argument of another actor. That is to say, an actor that makes a deliberative intervention is an actor that takes an argumentative stance on an issue which can be read as supporting or opposing the argumentative stance taken by another actor in the same field on the same issue.

Our coding breaks each deliberative intervention down into its elementary units along the structure of its linguistic grammar (Tilly 1995; Franzosi 2004). In particular, we focus on (i) the location of the intervention (where and when it occurred); (ii) the subject of the intervention (the actor who makes the intervention); (iii) the target of the intervention (the actor supported or opposed by the intervention); (iv) the policy issue taken up in the intervention (the specific subject matter on which the subject intervenes); (v) the values that are used to frame the deliberative intervention; and (vi) the three general requirements of good deliberation discussed above (acceptable language, supporting arguments and appeals to the general interest). All of this information is coded in machine-readable format through SPSS and analysed through standard statistical tools. As regards the coding of our three deliberative requirements, we start by seeing if actors couch their interventions in language that is acceptable (e.g. because it is respectful or inclusive) or unacceptable (e.g. because it is offensive or designed to manipulate). We then check for the presence of a supporting argument and, more specifically, whether arguments are valid or spurious. ${ }^{2}$ Finally, we check whether the argument contains an appeal to a particular interest (e.g. the actor appeals only to the good of its own ethnic group) or to a general interest (e.g. the actor appeals to the good of society at large, rather than just to the good of its own ethnic group).

Having assessed the field in terms of the quality of its deliberative interventions, network analysis then allows us to assess political integration in terms of relational dynamics amongst actors. Here, we rely on network measures (Knoke and Kuklinsky 1982; Wasserman and Faust 1994; Scott 2000) to assess patterns of relationships that actors, and specifically Muslims, forge with other actors. In particular, we focus on two main types of tie amongst actors, namely ties of support and ties of dissent (and hence the constellations of support and/or dissent which those ties form). As already noted, the literature on 'group polarisation' suggests that we 
should worry greatly if it turns out that Muslim actors talk only amongst themselves or, by corollary, only side with one another. In contrast, a more encouraging picture would be one in which Muslims engage in an extensive web of different types of relationships with a large variety of actors, thereby avoiding the creation, consolidation or deepening of divisions in the field.

Thus, the second component of our research involves a different treatment of our data, as it rests upon the construction of matrices of ties rather than on the coding of attributes for each deliberative intervention. Since our data are retrieved from newspapers, our concern is not with actors that argue back and forth in face-to-face contexts. Instead, we look for patterns of support or dissent so as to detect underlying structures of alliances and oppositions in the overall field. To this end, each actor is treated as a nodal focus from which ties of support and/or dissent radiate to other nodes-for example, when actor $A$ says that it supports actor $B^{\prime}$ s position on the public funding of religious schools while actor $C$ says that it opposes $B^{\prime}$ s position. Support and dissent are defined strictly, as we exclude actors that have engaged only in occasional relationships of this kind, producing no durable ties. Specifically, in seeking to capture the recursive nature of political argument, our operationalisation of a tierequires that two actors have referred to each other at least three times. If they do not meet this strict requirement, they do not feature in our analysis.

Network analysis offers a number of different quantitative measures that can then be used to assess empirically both the overall shape of the field and the specific position of Muslim actors within it. Three measures are especially relevant to our inquiry. To begin with, 'density' gives us a ready sense of the degree of political integration (or lack thereof) in the field. It is usually defined as the ratio of actual ties to all possible ties (e.g. Wasserman and Faust 1994, 181). Density allows us to assess the overall degree of support and dissent in the field at an initial, aggregated level.

Network analysis also enables us to say something more precise about the actual position each actor occupies in the field (Scott 2000, 83-85). We make use of two particular measures to gauge the centrality of an actor, namely 'out-degree' and 'in-degree' (Knoke and Burt 1983). Out-degree calculates the number of ties radiating from an actor, whereas in-degree calculates the number of ties radiating toward the actor. A high number of ties radiating from an actor (out-degree) is a clear indication of its 'activism' (vis-à-vis other actors) in the field, while a high number of ties radiating towards an actor (in-degree) is a clear indication of its relevance (to other actors).

Finally, network analysis enables us to check for 'cliques', that is, blocks of actors that stand out within the larger network for the fact that they have all forged mutual ties with one another (be that a bloc that is forged while supporting the position of, for example, the government on a given issue or one that is forged while dissenting from that position). Otherwise put, a clique is a group of actors in which each actor is directly tied to every other and hence where cohesion is at its highest (Doreian 1979, 51-52; Scott 2000, 114-115). 
Our data on interventions and networks have been retrieved from the analysis of two widely read British newspapers, The Guardian and The Times, during the course of 2007. Although we accept that two newspapers cannot allow for a comprehensive analysis, we chose these two newspapers because each is a broadsheet newspaper with a long-standing reputation in terms of consistent and detailed coverage of news. We also chose them because together they offer a balanced left vs. right (labour vs. conservative) perspective. Following Statham et al. (2005), we have also tried to minimise the problem of description bias by only coding direct statements (usually, deliberative interventions are surrounded, wholly or partly, by inverted comas) and excluding secondary or indirect comments and evaluations by newspaper editors or reporters. We chose 2007 because we sought to gain at least some distance from the events of 2005, and in particular the London bombings, and hence to get a more 'stable' view of deliberative interventions in the field.

It should be noted that our analysis does not depend on any preconceived, 'essentialised' notion of what it means to be a 'Muslim' (or 'non-Muslim'). There may or may not be a relatively coherent and identifiable bloc within the British polity that can be labeled as 'Muslim'; and it may or may not be the case that the Muslim actors whose interventions we analyse are representative of that bloc. Our analysis does not take a position on these issues. Rather, an actor is coded as a 'Muslim' actor only if that actor unambiguously self-identifies as such or when they explicitly speak on behalf of a Muslim organization.

Of course, we recognize that all newspapers are biased to one extent or another (McQuail 1992, 193-195; Boomgaarden and Vliegenthart 2009), and so one may have more general concerns about the representativeness of our data. ${ }^{3}$ Of particular relevance in the present context is criticism of selection bias (McCarthy et al. 1996; Hocke 1998; Oliver and Maney 2000; Myers and Caniglia 2004) which points to the risk of portraying a distorted deliberative reality. Yet there are also grounds for arguing that the problem of selection bias should not be overplayed. For better or worse, newspaper reporting plays its part in constituting the world in which we live. Quite simply, one 'does not need to adhere to the fashion for radical constructivism and post-modernism to recognise that the mass media contribute to the symbolic construction of realities' (Peters et al. 2008, 139). Newspapers may report only a small number of deliberative interventions. Yet to a considerable extent, actors can only deliberate about the issues that are made publicly available to them. As such, our analysis supposes that strong selection mechanisms in the public sphere forge the borders within which deliberative interventions can occur.

\section{Findings}

Our findings cover a broad range of actors and a large number of deliberative interventions $(n=1007)$. Table 1 shows which types of actors have made deliberative interventions and how often. We also aggregate scores so as to distinguish between the policy, intermediate and broader public domains.

Taken together, formal institutional actors account for 37.9 per cent of deliberative interventions. Civil society actors (including individuals) account for over half of all interventions (51.7 per cent). This suggests that, in contrast to a typical 'client 
JOBNAME: No Job Name PAGE: 10 SESS: 17 OUTPUT: Wed Nov 28 14:21:19 2012 SUM: 66682D30

/v2501/blackwell/B_journals/bjpi_v0_i0/bjpi_12003

Table 1: Deliberative Interventions: Actors

\begin{tabular}{|c|c|}
\hline Government & $12.5(126)$ \\
\hline Parliament & $5.1(51)$ \\
\hline Judiciary & $8.0(81)$ \\
\hline Police and security agencies & $6.9(69)$ \\
\hline Executive agencies & $5.5(55)$ \\
\hline All Institutional Actors & $37.9(382)$ \\
\hline Media & $4.9(49)$ \\
\hline Political parties & $2.9(29)$ \\
\hline Employers' organisations & $0.9(9)$ \\
\hline Unions and employees & $1.8(18)$ \\
\hline All Intermediate Actors & $10.4(105)$ \\
\hline Religious or ethnic minority actors & $16.3(164)$ \\
\hline Pro-minority actors & $2.5(25)$ \\
\hline Civil society actors & $13.1(132)$ \\
\hline Minority religious or ethnic extremists & $0.5(5)$ \\
\hline Extreme right & $0.1(1)$ \\
\hline Individuals & $19.2(193)$ \\
\hline All Civil Society Actors & $51.7(520)$ \\
\hline Total & $100.0(1007)$ \\
\hline \multicolumn{2}{|c|}{$\begin{array}{c}\text { Table 2: Deliberative Interventions: Muslim Actors } \\
\text { Comparison to Other Actors }\end{array}$} \\
\hline Muslims & $12.5(126)$ \\
\hline Other religious minorities & $4.5(45)$ \\
\hline Other (non-religious) minority actors & $3.8(38)$ \\
\hline All other actors & $79.2(798)$ \\
\hline Total & $100.0(1007)$ \\
\hline
\end{tabular}

politics' analysis, the field of ethnic relations is notable for the key role played by non-governmental actors generally. ${ }^{4}$ This impression is reinforced by the fact that intermediate actors (including trade unions, political parties and the media) are much less visible than one might have expected (10.4 per cent), especially in view of their traditional role as 'gatekeepers' between the policy and public domains.

However, within the broad category of civil society actors, religious and ethnic minorities are clearly visible (16.3 per cent). And on top of not having to rely on intermediate actors, they do not need to rely on pro-minorities organisations either (just 2.5 per cent). Table 2 tells us about how minorities feature in relation to one another; in this case, the same deliberative interventions are analysed in terms of whether actors belong to the Muslim minority, to other minorities, or to no minority at all. ${ }^{5}$ 
JOBNAME: No Job Name PAGE: 11 SESS: 17 OUTPUT: Wed Nov 28 14:21:19 2012 SUM: 66C3CF10

/v2501/blackwell/B_journals/bjpi_v0_i0/bjpi_12003

DELIBERATION NETWORKS AND BRITISH MUSLIMS

Table 3: Quality of Deliberation: Use of Language

\begin{tabular}{|c|c|c|c|}
\hline$\%$ & Unacceptable & Acceptable & Total \\
\hline Institutional actors & $12.6(48)$ & 87.4 (334) & 100.0 \\
\hline Intermediate actors & $25.8(27)$ & $74.2(78)$ & $100.0(105)$ \\
\hline $\begin{array}{l}\text { Civil society organisations } \\
\text { (excluding all religious } \\
\text { or ethnic minority } \\
\text { organisations) }\end{array}$ & $6.3(10)$ & 93.7 (148) & $100.0(158)$ \\
\hline $\begin{array}{l}\text { Religious or ethnic } \\
\text { minority organisations } \\
\text { (excluding Muslim } \\
\text { organisations) }\end{array}$ & $6.0(4)$ & $94.0(63)$ & $100.0(67)$ \\
\hline $\begin{array}{l}\text { Individuals (excluding } \\
\text { Muslims) }\end{array}$ & $18.9(32)$ & 81.1 (137) & 100.0 \\
\hline All non-Muslims & 13.7 (121) & $86.3(760)$ & 100.0 \\
\hline Muslim actors & $13.5(17)$ & $86.5(109)$ & $100.0(126)$ \\
\hline Total & 13.7 (138) & $84.5(851)$ & $100.0(1007)$ \\
\hline
\end{tabular}

Of the many minority actors that intervene in the field, Muslims feature most. In fact, they intervene more than all other minority actors combined. In one sense, this is understandable, since, as noted above, the integration of Muslims living in Britain has been hotly debated in recent years. Yet in another sense, the fact that Muslims intervene more than all other minority actors combined is surprising. Within the ethnic relations debate, a great deal of emphasis has been placed on the dangers of 'communitarianism', and in particular on the idea that many Muslims wish to close themselves off from engaging in an extensive dialogue with the broader society. Our data suggest that this worry may be overstated.

The mere fact that an actor intervenes in a field suggests that they see some value in engaging with other actors. Yet before we can arrive at anything approaching a determinate judgement about Muslim actors-in comparison to other actors in the field-we need to know whether or to what extent they meet our three requirements of good deliberation. Table 3 allows us to get some initial sense of the way that Muslims deliberate. ${ }^{6}$

More than 86 per cent of all interventions made by non-Muslim actors (760 out of 881) were couched in an acceptable language, while slightly less than 15 per cent (121 out of 881) were couched in an unacceptable language. As Table 3 shows, the interventions Muslim actors make are just about as likely to be marked by language that is broadly acceptable (109 out of 126), with no relationship at work between the type of actor-whether Muslim or non-Muslim-and the type of language (chi-square test is not significant). That is, for Muslims, acceptable language is the norm, just as it is for non-Muslims. 
JOBNAME: No Job Name PAGE: 12 SESS: 17 OUTPUT: Wed Nov 28 14:21:19 2012 SUM: 7011A305

/v2501/blackwell/B_journals/bjpi_v0_i0/bjpi_12003

Table 4: Quality of Deliberation: Supporting Arguments

\begin{tabular}{|c|c|c|c|c|}
\hline$\%$ & $\begin{array}{l}\text { Spurious } \\
\text { argument }\end{array}$ & $\begin{array}{c}\text { No } \\
\text { argument }\end{array}$ & $\begin{array}{c}\text { Valid } \\
\text { argument }\end{array}$ & Total \\
\hline Institutional actors & $7.3(26)$ & $18.4(65)$ & $74.3(263)$ & $100.0(354)$ \\
\hline Intermediate actors & $17.7(17)$ & $29.2(28)$ & $53.1(51)$ & $100.0(96)$ \\
\hline $\begin{array}{l}\text { Civil society organisations } \\
\text { (excluding all religious } \\
\text { or ethnic minority } \\
\text { organisations) }\end{array}$ & $1.3(2)$ & $16.0(24)$ & $82.7(124)$ & $100.0(150)$ \\
\hline $\begin{array}{l}\text { Religious or ethnic } \\
\text { minority organisations } \\
\text { (excluding Muslim } \\
\text { organisations) }\end{array}$ & $5.2(3)$ & $17.2(10)$ & 77.6 (45) & $100.0(58)$ \\
\hline $\begin{array}{l}\text { Individuals (excluding } \\
\text { Muslims) }\end{array}$ & $17.9(27)$ & 29.8 (45) & $52.3(79)$ & $100.0(151)$ \\
\hline All non-Muslims & $9.3(75)$ & $21.3(172)$ & $69.5(562)$ & $100.0(809)$ \\
\hline Muslim actors & $7.2(8)$ & $21.6(24)$ & 71.2 (79) & $100.0(111)$ \\
\hline Total & $9.0(83)$ & $21.3(196)$ & $69.7(641)$ & $100.0(920)^{\ddagger}$ \\
\hline $\begin{array}{l}\text { Iudes deliberative interventions } \\
\text { Ial statement in response to a } \\
7 \mathrm{~ns} \\
0 ; P<0.05 ; P<0.01 ; P<0.001\end{array}$ & clarificatic & supportin & & licable, $\mathrm{fc}$ \\
\hline
\end{tabular}

As we see from Table 4, non-Muslim actors meet the second requirement of having to provide a valid supporting argument about two-thirds of the time (562 out of 809 ). Only a small number of interventions by non-Muslim actors (75 out of 809) contain a spurious argument, while non-Muslim actors fail to provide any argument (when the need for an argument was clearly implied) at all about one fifth of the time. Our data show that Muslim actors are just as likely as any other actor to offer a valid supporting argument. In fact, the fit between Muslim and non-Muslim actors in terms of percentages is strikingly close across all three value labels, with no relationship at work between the type of actor-whether Muslim or non-Muslimand the type of argument is made (chi-square test is once again not significant).

Our distinction between appealing to the general interest and appealing to a particular interest is of signal importance in any comparison of how Muslim and non-Muslim actors deliberate. In principle, if an actor only sees an issue narrowly from its own perspective when it is also clearly possible to take a broader view of that issue, then that actor is not thinking about how its views and opinions stand to affect other actors in society. As Table 5 shows, non-Muslim actors appeal to the general interest about two fifths of the time (298 out of 740 ).

More specifically, institutional actors appeal to the general interest about nearly half of the time (45.9 per cent), with intermediary actors scoring equally high (45.1 per cent). Civil society actors also score relatively well, appealing to the general interest about 43 per cent of the time. Interestingly, other (i.e. non-Muslim) religious or 
JOBNAME: No Job Name PAGE: 13 SESS: 17 OUTPUT: Wed Nov 28 14:21:19 2012 SUM: 700DAD27

/v2501/blackwell/B_journals/bjpi_v0_i0/bjpi_12003

DELIBERATION NETWORKS AND BRITISH MUSLIMS

Table 5: Quality of Deliberation: Appeals to Interest

\begin{tabular}{|c|c|c|c|c|}
\hline$\%$ & $\begin{array}{c}\text { Particular } \\
\text { interest }\end{array}$ & $\begin{array}{l}\text { General } \\
\text { interest }\end{array}$ & $\begin{array}{l}\text { No clearly } \\
\text { identifiable } \\
\text { interest }\end{array}$ & Total \\
\hline Institutional actors & $12.8(42)$ & 45.9 (151) & $41.3(136)$ & 100.0 \\
\hline Intermediate actors & $8.8(8)$ & 45.1 (41) & 46.2 (42) & $100.0(91)$ \\
\hline $\begin{array}{l}\text { Civil society organisations } \\
\text { (excluding all religious } \\
\text { or ethnic minority } \\
\text { organisations) }\end{array}$ & $20.0(28)$ & $42.9(60)$ & $37.1(52)$ & $100.0(140)$ \\
\hline $\begin{array}{l}\text { Religious or ethnic } \\
\text { minority organisations } \\
\text { (excluding Muslim } \\
\text { organisations) }\end{array}$ & $47.4(27)$ & 42.1 (24) & $10.5(6)$ & $100.0(57)$ \\
\hline $\begin{array}{l}\text { Individuals (excluding } \\
\text { Muslims) }\end{array}$ & $7.3(9)$ & $17.9(22)$ & 74.8 (92) & 100. (123) \\
\hline All non-Muslims & $15.4(114)$ & 40.3 (298) & 44.3 (328) & $100.0(740)$ \\
\hline Muslims & 18.0 (18) & $28.0(28)$ & 54.0 (54) & $100.0(100)$ \\
\hline Total & $15.7(132)$ & 38.8 (326) & $45.5(382)$ & $100.0(840)^{\ddagger}$ \\
\hline
\end{tabular}

${ }^{\ddagger} N$ excludes deliberative interventions that did not involve interests, for example, purely factual interventions, and hence where this category was not applicable $\chi^{2} 5.609^{\dagger}$

${ }^{+} P<0.10$; * $P<0.05$; ${ }^{* *} P<0.01$; *** $P<0.001$

ethnic minority actors appeal to the general interest 42 per cent of the time. Yet, in the majority of cases (328 out of 740 ), non-Muslim actors do not refer to either a clearly identifiable particular interest or a clearly identifiable general interest. In comparison to non-Muslim actors, Muslim actors score relatively poorly on this measure, appealing to a general interest just over a quarter of the time (28 per cent). This time there is an important correlation at work between the type of actor-whether Muslim or non-Muslim - and the type of appeal to interest (with chi-square test close to full significance). That is, for Muslims, appealing to the general interest is certainly not as likely an occurrence as it is for non-Muslims.

Now that we have seen how Muslims deliberate in comparison to other actors, we can move on to the second component of our analysis which appraises their political integration in relational terms. As we explained earlier, we begin by assessing the extent to which actors in general and Muslims in particular have forged ties of support or ties of dissent in the field. We then examine whether those ties of support and dissent are broken into cliques, which in turn enables us to detect entrenched blocks that may signal on-going processes of polarisation.

As a starting point, Figure 1 conveys a broad picture of ties of support in the field. Overall density is 0.23 , which is to say that 23 per cent of all possible ties of support have been created. Given that the field is comprised of actors as diverse as Parlia- 
JOBNAME: No Job Name PAGE: 14 SESS: 17 OUTPUT: Wed Nov 28 14:21:19 2012 SUM: 3E0C19B7

/v2501/blackwell/B_journals/bjpi_v0_i0/bjpi_12003

Figure 1: Ties of Support

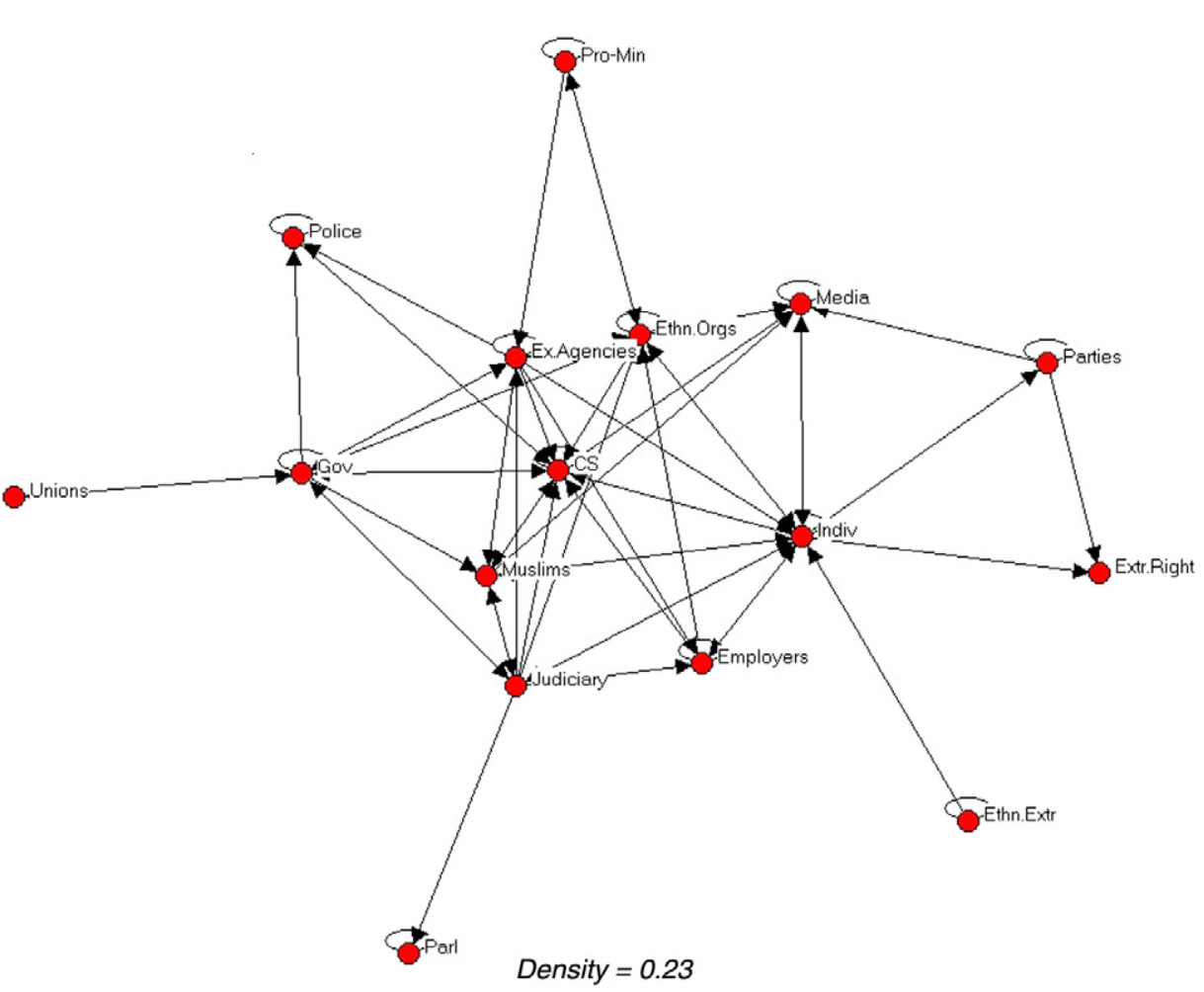

ment, the extreme right, and Muslims, this figure indicates an extensive presence of relationships of mutual support in the field. Muslims are situated close to government, civil society organisations and the judiciary. By contrast, Muslims are relatively distant from actors whom one might naturally think of as their most natural interlocutors, such as pro-minority actors.

Continuing our analysis of networks of support, Table 6 enables us to gain a more nuanced understanding of the position of Muslims by considering our two indicators of centrality, that is, in-degree and out-degree. ${ }^{7}$ Muslims have a relatively high in-degree score, signalling that they can count on the support of a relatively large number of non-Muslim actors. Along this dimension, only three actors-civil society organisations, individuals, and other religious and ethnic minority actorsoccupy a more central position within the network as a whole. By contrast, intermediary actors such as political parties and the media have a relatively low in-degree score.

Out-degree scores are roughly consistent with in-degree scores. Muslims have a relatively high out-degree score vis-à-vis other actors, which suggests that they are relatively active in terms of building ties of support. Intermediate actors again stand out for their low scores. In the case of the judiciary, there is a crucial mismatch between in-degree and out-degree (given that the latter is nearly three times the 
JOBNAME: No Job Name PAGE: 15 SESS: 17 OUTPUT: Wed Nov 28 14:21:19 2012 SUM: 63791263

/v2501/blackwell/B_journals/bjpi_v0_i0/bjpi_12003

DELIBERATION NETWORKS AND BRITISH MUSLIMS

Table 6: Networks of Support: Actors' Degree

\begin{tabular}{lcc}
\hline & & \\
& Out-Degree & In-Degree \\
\hline Government & 46.7 & 33.3 \\
Muslims & 26.7 & 33.3 \\
Religious or ethnic & 33.3 & 46.7 \\
$\quad$ minority organisations & & \\
$\quad$ (excluding Muslim & & \\
$\quad$ organisations) & & \\
Individuals & 53.3 & 46.7 \\
Judiciary & 53.3 & 20.0 \\
Civil society organisations & 26.7 & 53.3 \\
Executive agencies & 53.3 & 26.7 \\
Police and security & 6.7 & 13.3 \\
$\quad$ agencies & & \\
Pro-minority organisations & 13.3 & 6.7 \\
Parliament & 0.0 & 6.7 \\
Media & 6.7 & 13.3 \\
Political parties & 13.3 & 6.7 \\
Employers & 20.0 & 20.0 \\
Unions & 6.7 & 6.7 \\
Minority religious or & 6.7 & 0.0 \\
$\quad$ ethnic extremists & & \\
Extreme right & 0.0 & 13.3 \\
\hline
\end{tabular}

former), but this may have to do with the fact that the judiciary is a major pillar for the defence of minorities in the policy domain (Joppke 2001). Almost half of all actors have greater out-degree than in-degree scores, which suggests that many actors are not complacent about their position in the field.

Turning, then, to ties of dissent, Figure 2 shows that, with an overall density of 0.31 , many actors join together with other actors in forging ties of dissent. There is more dissent than support, but not drastically so for such a supposedly contentious field.

Muslim actors are now at the periphery of network, relatively distant from government and quite close to pro-minorities. In particular, as we can see in Table 7, Muslims engage in the building of ties of dissent with other actors more than other actors engage in building ties of dissent with Muslims. The position of government is perhaps as one might expect: In-degree is over three times higher than outdegree, and indeed government is by far the major target of dissent in the field, while government seems to have little interest in forging (or little need to forge) ties of dissent with other actors.

We now turn to the analysis of cliques in the field, focusing on specific network portions where actors all share a tie with each other. In particular, we measure how many times couples of actors share a tie across different cliques, while at the same time assessing the extent to which this configuration of repeated ties across over- 
JOBNAME: No Job Name PAGE: 16 SESS: 17 OUTPUT: Wed Nov 28 14:21:19 2012 SUM: 40DE46BB

Figure 2: Ties of Dissent

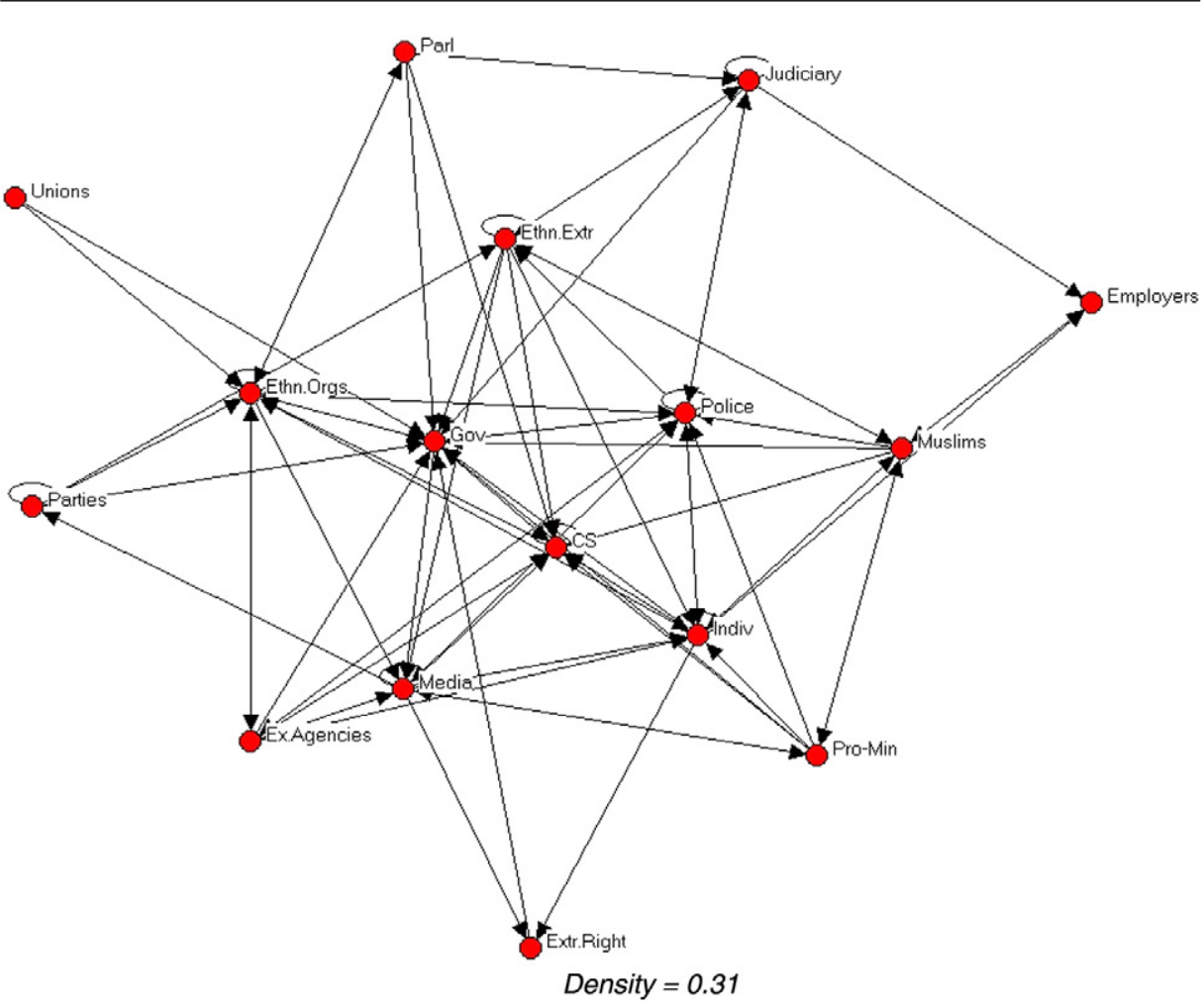

lapping cliques amounts to a meaningful relational pattern in the field. ${ }^{8}$ As we see in Table 8, Muslims are present in about a third of cliques of support and in about a third of cliques of dissent. Muslims share ties of support with civil society and executive agencies across three different cliques; they share two cliques with individuals and the judiciary and one clique with government and the media. As regards ties of dissent, Muslims share five cliques with individuals, four cliques with government, two cliques with civil society, pro-minorities, ethnic extremists and the police, and one clique with employers.

By broadening our analysis to all cliques in the field, we can detect blocks made of overlapping cliques. ${ }^{9}$ Figures 3 and 4 shed light on overlapping cliques of support and dissent respectively.

Having matched blocks of support with blocks of dissent, we can identify four main groups of actor, each linked to Muslim actors in a distinct type of relationship. First, actors such as the judiciary and executive agencies stand in (what might be termed) a relationship of consensus with Muslims, owing to the high connectedness of these actors within the same block of support coupled with their unconnectedness in terms of dissent. Secondly, actors such as pro-minorities and ethnic extremists stand in a relationship of opposition to Muslims, owing to the high connectedness of these actors within the same block of dissent coupled with their unconnectedness in 
JOBNAME: No Job Name PAGE: 17 SESS: 17 OUTPUT: Wed Nov 28 14:21:19 2012 SUM: 63514F6D

/v2501/blackwell/B_journals/bjpi_v0_i0/bjpi_12003

DELIBERATION NETWORKS AND BRITISH MUSLIMS

Table 7: Networks of Dissent: Actors' Degree

\begin{tabular}{lcc}
\hline & & \\
& Out-Degree & In-Degree \\
\hline Government & 26.7 & 86.7 \\
Muslims & 46.7 & 26.7 \\
Religious or ethnic & 33.3 & 53.3 \\
$\quad$ minority organisations & & \\
$\quad$ (excluding Muslim & & \\
$\quad$ organisations) & & \\
Individuals & 53.3 & 53.3 \\
Judiciary & 26.7 & 20.0 \\
Civil society organisations & 20.0 & 53.3 \\
Executive agencies & 40.0 & 20.0 \\
Police and security & 46.7 & 46.7 \\
$\quad$ agencies & & \\
Pro-minority organisations & 40.0 & 13.3 \\
Parliament & 26.7 & 6.7 \\
$\quad$ Media & 40.0 & 40.0 \\
Political parties & 20.0 & 13.3 \\
Employers & 13.3 & 20.0 \\
$\quad$ Unions & 13.3 & 0.0 \\
Minority religious or & 40.0 & 26.7 \\
$\quad$ ethnic extremists & & \\
Extreme right & 6.7 & 13.3 \\
\hline
\end{tabular}

Table 8: Muslims in Cliques of Support and Dissent

Support Dissent

(9 cliques in total) (18 cliques in total)

1: Muslims CS Indiv 1: Gov Muslims CS Judiciary Ex.Agencies Pro-Min Indiv

2: Muslims Media CS 2: Gov Muslims Indiv Ex.Agencies Pro-Min Indiv Police

3: Gov Muslims CS 3: Gov Muslims CS Judiciary Ex.Agencies Ethn.Extr Indiv

4: Gov Muslims Ethn.Extr Indiv Police

5: Muslims Indiv Employers 
JOBNAME: No Job Name PAGE: 18 SESS: 17 OUTPUT: Wed Nov 28 14:21:19 2012 SUM: 35C3D372

/v2501/blackwell/B_journals/bjpi_v0_i0/bjpi_12003

Figure 3: Overlapping Cliques of Support

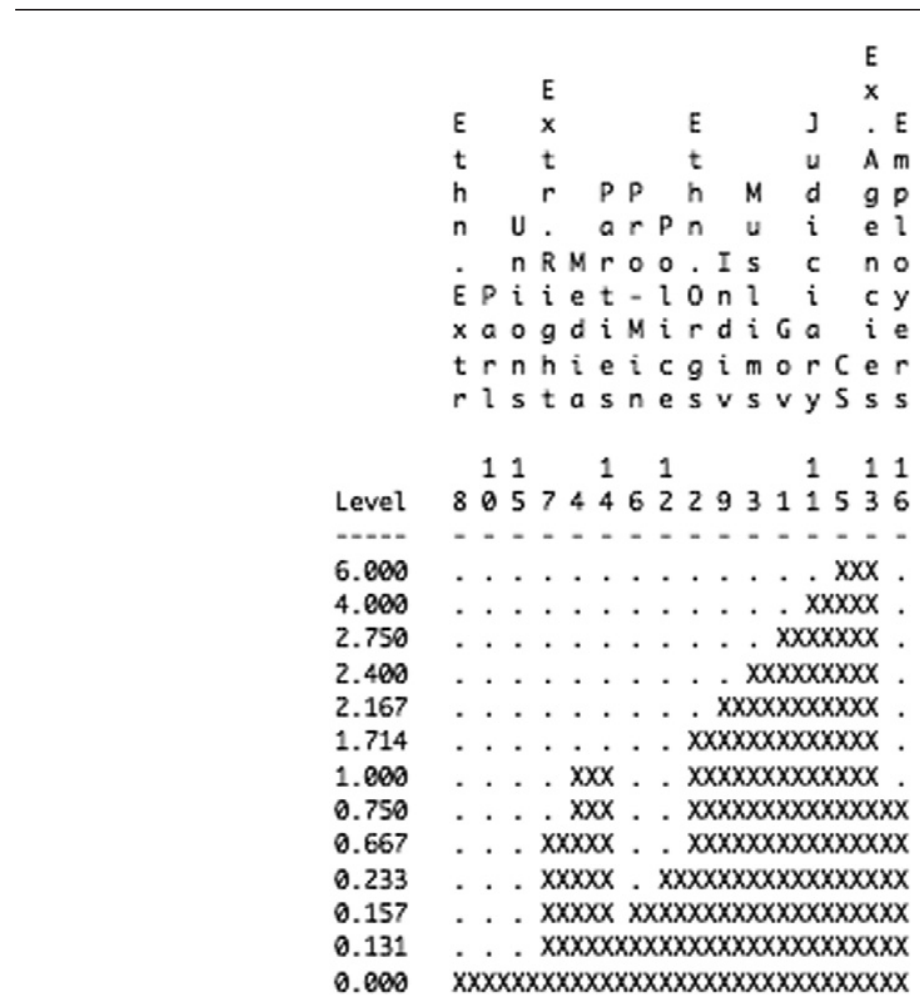

terms of support. Civil society actors stand in a pragmatic relationship with Muslims, owing to their connectedness within blocks of both support and dissent at one and the same time. Lastly, actors such as unions and employers form a fourth group that stands out for its indifference vis-à-vis Muslims, owing to their striking unconnectedness in terms of both support and dissent.

\section{Discussion}

Muslim actors are just as likely as any other actor in the field of ethnic relations in Britain to use acceptable language and, moreover, to provide a valid argument in support of the positions that they take. To this extent, there is no disjunction between how Muslims deliberate and the broader policy field within which their interventions are located. However, when it comes to the requirement of appealing to the general interest, Muslim actors score relatively poorly: they only appeal to the general interest about a quarter of the time.

Simply on the basis on this evidence, one might worry about the political integration of Muslims living in Britain. Yet as we have stressed from the outset, assumptions of this sort need to be systematically tested. Empirically-minded deliberative theorists have had much to say about whether the interventions actors make 
JOBNAME: No Job Name PAGE: 19 SESS: 17 OUTPUT: Wed Nov 28 14:21:19 2012 SUM: 41CEDC1A /v2501/blackwell/B_journals/bjpi_v0_i0/bjpi_12003

Figure 4: Overlapping Cliques of Dissent

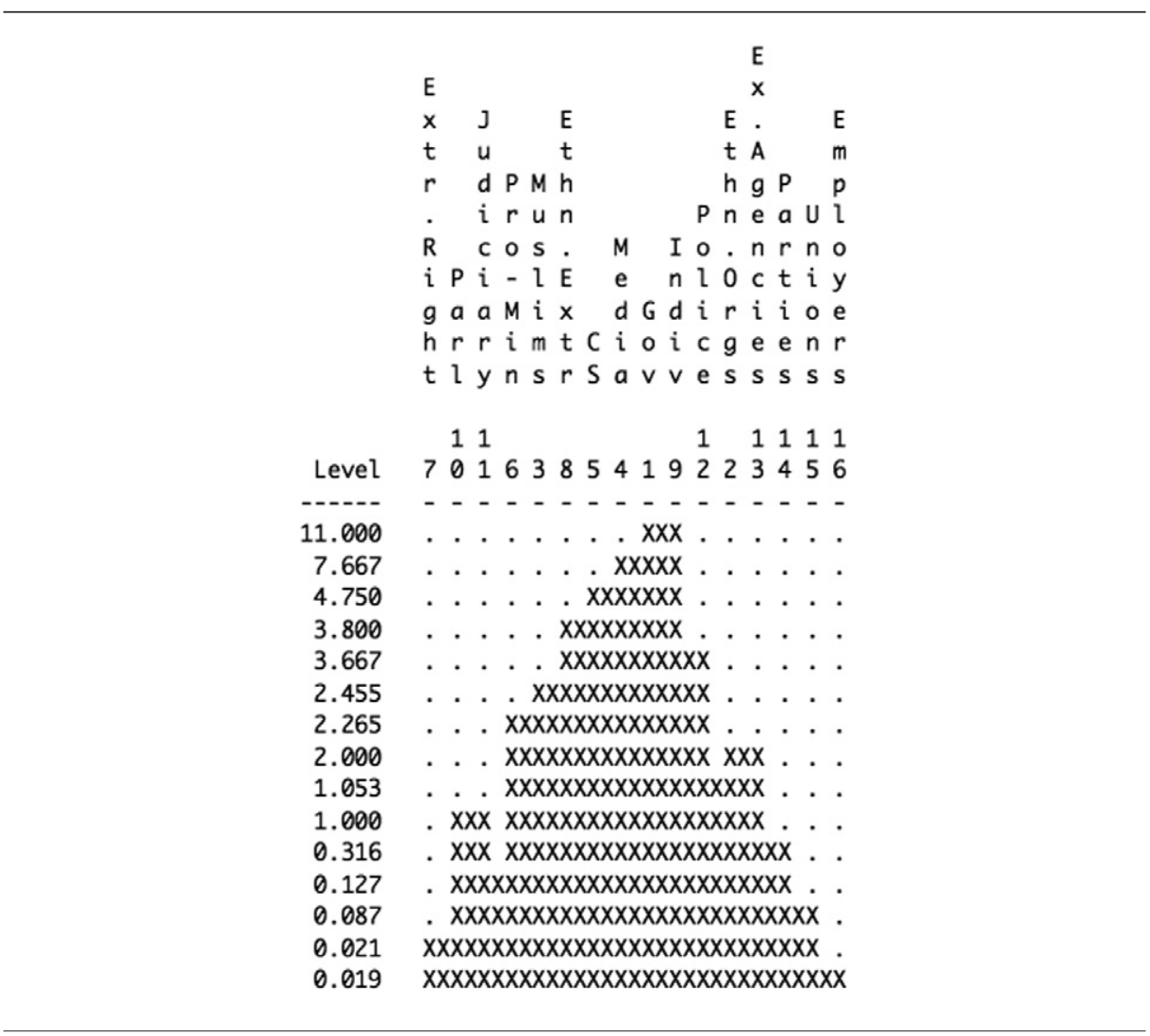

display the right sorts of attribute. Yet they have little to say about the relational dimensions of those interventions. Quantitative treatment of data in most deliberative studies, including, for example, studies which utilise the DQI mentioned earlier, has focused on how actors deliberate rather than on the linkages that they build.

To be sure, some scholars, most notably Donatella della Porta (2005), have already highlighted the importance of putting networks at the core of deliberative analysis. Yet, in della Porta's account, networks act as facilitators of deliberation that help to increase the capacity of actors to meet the requirements of good deliberation. In other words, they are taken as a variable that helps to explain why one actor deliberates better than another. In our analysis, by contrast, networks are treated as macro-level explananda, whose precise shape can tell us much about what public deliberation actually achieves-namely, relationships of consensus, opposition, pragmatism or perhaps even mutual indifference.

To assess those relationships, we consider not just the patterns of ties of support and dissent on which they rest, but also the cliques and cleavages with which they are bound up. We find that Muslim actors appear in about a third of cliques of support and dissent. The diverse composition of both sorts of clique is striking. But what is 
JOBNAME: No Job Name PAGE: 20 SESS: 17 OUTPUT: Wed Nov 28 14:21:19 2012 SUM: 87808635

/v2501/blackwell/B_journals/bjpi_v0_i0/bjpi_12003

even more striking is that cliques do not map onto cleavages. The field is, in fact, characterised by overlapping cliques rather than by deep cleavages that might signal a lack of political integration. We do not find evidence of 'group polarisation' and we think that worries about 'communitarianism' may be overstated.

That said, we agree that appealing to the general interest is, or at least can be, part of what it means to deliberate well. Yet the fact that Muslim actors score relatively poorly when it comes to appealing to the general interest does not seem to be a major impediment to their political integration. The reasons why are complex, but the following points strike us as especially noteworthy. Despite the fact that Muslim actors score relatively poorly in terms of appealing to the general interest, they can nevertheless count on the support of a relatively large number of non-Muslim actors for the positions that they take. Empirically, therefore, their failure to appeal to the general interest does not seem to have cost them their position in the field.

Overall, our sense is that Muslim actors are reasonably well integrated, despite what, for example, elements in the British popular press would have us believe. They clearly want to engage and clearly are engaged with a broad range of actors across both policy and public domains. Far from simply seeking to build ties of support or dissent with 'like-minded others', the relationships in which they stand to other actors are multifaceted and complex. Their deliberative interventions link them to a diverse range of actors, with variable mixtures of consensus, conflict, pragmatism and indifference. This complexity would need to be taken into account in any thorough assessment of the political integration of Muslims living in Britain. Of course, ours is only a small contribution in this direction, but we hope it is nevertheless telling. Beyond the particular case of Britain, we hope we have shown why deliberative democrats should expand the horizons of their research so as make the link between public deliberation and political integration more central to their concerns.

\begin{abstract}
About the Authors
Manlio Cinalli, Centre de recherches politiques de Sciences Po (CEVIPOF), CNRS, 75007, Paris, France, email: manlio.cinalli@sciences-po.fr
\end{abstract}

Ian O'Flynn, School of Geography, Politics and Sociology, Newcastle University, Newcastle upon Tyne NEl 7RU, UK, email: ian.o'flynn@ncl.ac.uk

\title{
Notes
}

Research for this article was kindly supported by the British Academy (grant SG-49492).

1. For example, Cantle 2001; Ouseley Report 2001; Home Office 2005; Meer 2006; Malik 2006/07; COIC 2007; Modood 2007; Policy Exchange 2007; Meer and Modood 2009.

2. A 'spurious' argument is one where there is no clear connection between the claim being made and the argument offered in support of it (e.g. 'John could not have planted the bomb because I know him to be a good father who pays his bills on time.'). By contrast, a 'valid' argument is one where, for example, the relevant facts or values on which the claim is based are clearly established and applicable, and where those same facts or values are plausibly connected to the conclusion drawn by the actor (e.g. 'John could not have planted the bomb because he is a pacifist and in any case was out of the country at the time').

3. See Earl et al. 2004 and Ortiz et al. 2005 for general overviews of criticisms of the use of newspaper data; for analyses that seek to relate such criticisms to the specific case of Muslims in Britain, see Richardson 2009 and Meer 2006. 
JOBNAME: No Job Name PAGE: 21 SESS: 17 OUTPUT: Wed Nov 28 14:21:19 2012 SUM: E87848DB /v2501/blackwell/B_journals/bjpi_v0_i0/bjpi_12003

4. Typically, on a 'client politics' analysis, political elites shape an expansionist multicultural agenda in 'hidden' agreement with the most powerful stakeholders and Muslim actors themselves, without engaging in an extensive dialogue with civil society actors across the public sphere more generally (e.g. Freeman 2002).

5. In Table 1, the variable is 'actor status'. Here, in Table 2, the variable is 'religion'. Hence, individuals from Table 1 with a clearly stated religious identity have been reassigned.

6. In this case, we aggregate figures in a way so as to consider both the 'status' attribute of Table 1 and the 'minority' attribute of Table 2 . This allows us to check both for the presence of some types of actors over others and for the contrast between Muslims and non-Muslims. The same logic underlies the construction of Tables 4 and 5 .

7. In-degree and out-degree scores are calculated by working out the ratio, that is, a proportion in percentage between the total ties an actor forges (in terms of in- or out-ties) and the total ties that that actor might possibly forge. For example, a score of 46.7 for in-degree means that the actor receives 46.7 per cent of all ties that it may receive (if all the other actors were forging out-ties with it). So, in one network with 1,000 actors, 46.7 means that the selected actor has 467 ties.

8. Formally, a clique is the maximum number of actors who have all possible ties present among themselves. Three is the minimum number of actors required to form a clique.

9. Here we proceed by identifying all couples of actors sharing a common presence in the same clique; we then build blocks of cliques around couples of actors, from couples sharing the highest number of cliques to couples with a lower number of cliques.

\section{Bibliography}

Berger, M., Galonska, C. and Koopmans, R. (2004) ‘Political integration by a detour?: Ethnic communities and social capital of migrants in Berlin', Journal of Ethnic and Migration Studies, 30:3, 491-507.

Bessette, J. (1994) The Mild Voice of Reason: Deliberative Democracy e American National Government (Chicago IL: University of Chicago Press).

Boomgaarden, H. and Vliegenthart, R. (2009) 'How news content influences anti-immigration attitudes: Germany, 1993-2005', European Journal of Political Research, 48:4, 516-542.

Bourdieu, P. (1986) 'The forms of capital', in J. Richardson (ed.), Handbook of Theory and Research for the Sociology of Education (Westport CT: Greenwood Press), 241-258.

Cantle, T. (2001) Community Cohesion: A Report of the Independent Review Team (London: HMSO).

Cinalli, M. (2004) Horizontal Networks Vs. Vertical Networks in Multi-Organisational Alliances: A Comparative Study of the Unemployment and Asylum Issue-Fields in Britain (EurPolCom working paper 8/04) (Leeds: University of Leeds).

Cinalli, M. (2007) ‘Between horizontal bridging and vertical governance: Pro-beneficiary movements in New Labour Britain', in D. Purdue (ed.), Civil Societies and Social Movements: Potentials and Problems (London: Routledge), 88-108.

Cohen, J. (1989) 'Deliberative democracy and democratic legitimacy', in A. Hamlin and P. Pettit (eds), The Good Polity (Oxford: Blackwell), 17-34.

Cohen, J. (1996) 'Procedure and substance in deliberative democracy', in S. Benhabib (ed.), Democracy and Difference: Contesting the Boundaries of the Political (Princeton NJ: Princeton University Press), 95-119.

Coleman, J. S. (1990) Foundations of Social Theory (Cambridge MA: Harvard University Press).

Commission on Integration and Cohesion (COIC) (2007) Our Shared Future: Themes, Messages and Challenges: A Final Analysis of Key Themes from the Commission on Integration and Cohesion Consultation (London: HMSO).

Della Porta, D. (2005) 'Deliberation in movement: Why and how to study deliberative democracy and social movements', Acta Politica, 40:3, 336-350.

Delli Carpini, M., Lomax Cook, F. and Jacobs, L. (2004) 'Public deliberation, discursive participation and citizen engagement: A review of the empirical literature', Annual Review of Political Science, 7, 315-344.

Diani, M. and McAdam, D. (2003) Social Movements and Networks: Relational Approaches to Collective Action (Oxford: Oxford University Press).

Dolezal, M., Helbling, M. and Hutter, S. (2010) 'Debating Islam in Austria, Germany and Switzerland: Ethnic citizenship, church-state relations and right-wing populism', West European Politics, 33:2, 171190.

(C) 2012 The Authors. British Journal of Politics and International Relations $\odot 2012$ Political Studies Association

BJPIR, 2012 
JOBNAME: No Job Name PAGE: 22 SESS: 17 OUTPUT: Wed Nov 28 14:21:19 2012 SUM: 2D03B02D

/v2501/blackwell/B_journals/bjpi_v0_i0/bjpi_12003

Doreian, P. (1979) 'On the delineation of small group structure', in H. C. Hudson (ed.), Classifying Social Data (San Francisco CA: Jossey-Bass), 215-230.

Dryzek, J. (2000) Deliberative Democracy and Beyond. Liberals, Critics, Contestations (Oxford: Oxford University Press).

Earl, J., Martin, A., McCarthy, J. and Soule, S. (2004) 'The use of newspaper data in the study of collective action', Annual Review of Sociology, 30, 65-80.

Elster, J. (1998) 'Deliberation and constitution making', in J. Elster (ed.), Deliberative Democracy (Cambridge: Cambridge University Press), 109-111.

Fennema, M. and Tillie, J. (1999) 'Political participation and political trust in Amsterdam: Civic communities and ethnic networks', Journal of Ethnic and Migration Studies, 25:4, 703-726.

Ferree, M., Gamson, W., Gerhards, J. and Rucht, D. (2002) Shaping Abortion Discourse: Democracy and the Public Sphere in Germany and the United States (Cambridge: Cambridge University Press).

Fishkin, J. (1995) The Voice of the People (New Haven CT: Yale University Press).

Fishkin, J. (2009) When the People Speak. Deliberative Democracy and Public Consultation (Oxford: Oxford University Press).

Fishkin, J. and Luskin, R. (2005) 'Experimenting with a democratic ideal: Deliberative polling and public opinion', Acta Politica, 40:3, 284-298.

Franzosi, R. (2004) From Words to Number: Narrative, Data, and Social Sciences (Cambridge: Cambridge University Press).

Freeman, G. P. (2002) 'Winners and losers: Politics and the costs and benefits of migration', in A. M. Messina (ed.), Western European Immigration and Immigration Policy (Westport CT: Praeger), 77-95.

Fung, A. (2003) 'Recipes for public spheres: Eight institutional design choices and their consequences', The Journal of Political Philosophy, 11:3, 338-367.

Giugni, M. and Passy, F. (2004) 'Migrant mobilization between political institutions and citizenship regimes: A comparison of France and Switzerland', European Journal of Political Research, 43:1, 51-82.

Gutmann, A. and Thompson, D. (1996) Democracy and Disagreement: Why Moral Conflict Cannot Be Avoided and What Should Be Done About It (Cambridge MA: Belknap Press).

Habermas, J. (1984) The Theory of Communicative Action Vol. 1: Reason and the Rationalization of Society, trans. T. McCarthy (Cambridge: Polity Press).

Habermas, J. (1987) The Theory of Communicative Action Vol. 2: Lifeworld and System: A Critique of Functionalist Reason, trans. T. McCarthy (Cambridge: Polity Press).

Habermas, J. (1991) Moral Consciousness and Communicative Action (Cambridge MA: MIT Press).

Habermas, J. (1996) Between Facts and Norms: Contributions to A Discourse Theory of Law and Democracy, trans. W. Rehg (Cambridge: Polity Press).

Home Office (2005) Life in the United Kingdom: A Journey to Citizenship (London: HMSO).

Hocke, P. (1998) 'Determining the selection bias in local and national newspaper reports on protest events', in D. Rucht, R. Koopmans and F. Neidhardt (eds), Acts of Dissent (Berlin: Edition Sigmas Rainier Bohn Verlag), 131-163.

Jacobs, D., Phalet, K. and Swyngedouw, M. (2004) 'Associational membership and political involvement among ethnic minority groups in Brussels', Journal of Ethnic and Migration Studies, 30:3, 543-559.

Jacobs, L., Cook, F. and Delli Carpini, M. (2009) Talking Together: Public Deliberation and Political Participation in American (Chicago IL: University of Chicago Press).

Joppke, C. (2001) 'The legal-domestic sources of immigrant rights', Comparative Political Studies, 34:4, 339-366.

Knoke, D. and Burt, R. S. (1983) 'Prominence', in R. S. Burt and M. J. Minor (eds), Applied Network Analysis: A Methodological Introduction (Beverly Hills CA: Sage), 195-222.

Knoke, D. and Kuklinsky, J. (1982) Network Analysis (London: Sage).

Koopmans, R. and Statham, P. (1999) 'Political claims analysis: Integrating protest event and political discourse approaches', Mobilization, 4:2, 203-222.

Kriesi, H-P., Koopmans, R., Duyvendak, J. W. and Giugni, M. (1995) New Social Movements in Western Europe (Minneapolis MN: University of Minnesota Press).

Lin, N. (1999) 'Social networks and status attainment', Annual Review of Sociology, 25, 467-487.

Lin, N. (2001) Social Capital: A Theory of Social Structure and Action (Cambridge: Cambridge University Press). 
JOBNAME: No Job Name PAGE: 23 SESS: 17 OUTPUT: Wed Nov 28 14:21:19 2012 SUM: 1F1FB0C8

/v2501/blackwell/B_journals/bjpi_v0_i0/bjpi_12003

McCarthy, J. D., McPhail, C. and Smith, J. (1996) 'Images of protest: Estimating selection bias in media coverage of Washington demonstrations, 1982, 1991', American Sociological Review, 61, 478-499.

Malik, K. (2006/07) 'The crisis of multiculturalism: British society between diversity and integration', Jewish Policy Research News, Winter, 3.

Mansbridge, J. (1980) Beyond Adversary Democracy (Chicago IL: University of Chicago Press).

Mansbridge, J. (1999) 'Everyday talk in the deliberative system', in S. Macedo (ed.), Deliberative Politics: Essays on Democracy and Disagreement (Oxford: Oxford University Press), 211-239.

Mansbridge, J. (2010) 'The place of self-interest and the role of power in deliberative democracy', The Journal of Political Philosophy, 18:1, 64-100.

McQuail, D. (1992) Media Performance: Mass Communication and the Public Interest (London: Sage).

Meer, N. (2006) ' "Get off your knees": Print media, public intellectuals and Muslims in Britain', Journalism Studies, 7:1, 35-59.

Meer, N. and Modood, T. (2009) 'The multicultural state we're in: Muslims, "multiculture" and the "civic re-balancing" of British multiculturalism', Political Studies, 57:3, 473-497.

Mendelberg, T. (2002) 'The deliberative citizen: Theory and evidence', in M. Delli Carpini, L. Huddy and R. Shapiro (eds), Research in Micropolitics: Political Decision-making, Deliberation and Participation (Greenwich CT: JAI Press), 151-193.

Mill, J. S. [1861] (1991) 'Considerations on representative government', in J. Gray (ed.), John Stuart Mill: On Liberty and Other Essays (Oxford: Oxford University Press), 203-467.

Modood, T. (2007) Multiculturalism: A Civic Idea (Cambridge: Polity Press).

Morales, L. and Giugni, M. (2011) Social Capital, Political Participation and Migration in Europe (Basingstoke: Palgrave Macmillan).

Mutz, D. (2008) 'Is deliberative democracy a falsifiable theory?', Annual Review of Political Science, 11, $521-538$.

Myers, D. and Caniglia, B. (2004) 'All the rioting that's fit to print: Selection effects in national newspaper coverage of civil disorders, 1968-1969', American Sociological Review, 69:4, 519-543.

O’Flynn, I. (2010) 'Deliberating about the public interest', Res Publica, 16:3, 299-315.

Oliver, P. and Maney, G. (2000) 'Political processes and local newspaper coverage of protest events: From selection bias to triadic interactions', American Journal of Sociology, 106:2, 463-505.

Ortiz, D. G., Myers, D., Walls, N. E. and Diaz, M.-E. (2005) 'Where do we stand with newspaper data?', Mobilization, 10:3, 379-419.

Ouseley Report (2001) Community Pride Not Prejudice: Making Diversity Work in Bradford (Bradford: Bradford Vision).

Page, B. (1996) Who Deliberates? Mass Media in Modern Democracy (Chicago IL: University of Chicago Press).

Peters, B., Schultz, T. and Wimmel, A. (2008) 'Contemporary journalism and its contribution to a discursive public sphere', in H. Wessler (ed.), Public Deliberation and Public Culture: The Writings of Bernhard Peters, 1993-2005, trans. K. Tribe (Basingstoke: Palgrave Macmillan), 134-159.

Policy Exchange (2007) Living Apart Together: British Muslims and the Paradox of Multiculturalism (London: Policy Exchange).

Putnam, R. (1993) Making Democracy Work: Civic Traditions in Modern Italy (Princeton NJ: Princeton University Press).

Putnam, R. (2000) Bowling Alone: The Collapse and Revival of American Community (New York: Simon \& Schuster)

Rawls, J. (1996) Political Liberalism (New York: Columbia University Press).

Richardson, J. (2009) 'Get shot of the lot of them: Election reporting of Muslims in British newspapers', Patterns of Prejudice, 43:3-4, 355-377.

Sanders, L. (1997) 'Against deliberation', Political Theory, 25:3, 347-376.

Scott, J. (2000) Social Network Analysis: A Handbook (London: Sage).

Searing, D., Solt, F., Johnston Connover, P. and Crewe, I. (2007) 'Public discussion and the deliberative system: Does it make better citizens?', British Journal of Political Science, 37:4, 587-618.

Smith, G. (2009) Democratic Innovations: Designing Institutions for Citizen Participation (Cambridge: Cambridge University Press).

(C) 2012 The Authors. British Journal of Politics and International Relations $\odot 2012$ Political Studies Association BJPIR, 2012 
JOBNAME: No Job Name PAGE: 24 SESS: 17 OUTPUT: Wed Nov 28 14:21:19 2012 SUM: 8F2F37DC /v2501/blackwell/B_journals/bjpi_v0_i0/bjpi_12003

Statham, P., Koopmans, R., Giugni, M. and Passy, R. (2005) 'Resilient or adaptable Islam? Multiculturalism, religion and migrants' claims-making for group demands in Britain, the Netherlands and France', Ethnicities, 5:4, 427-459.

Steenbergen, M., Bächtiger, A., Spörndli, M. and Steiner, J. (2003) 'Measuring political deliberation: A discourse quality index', Comparative European Politics, 1:1, 21-48.

Sunstein, C. (2002) 'The law of group polarization', The Journal of Political Philosophy, 10:2, 175-195.

Tarrow, S. (1998) Power in Movement (Cambridge: Cambridge University Press).

Thompson, D. (2008) 'Deliberative democratic theory and empirical political science', Annual Review of Political Science, 11, 297-320.

Tilly, C. (1995) Popular Contention in Great Britain, 1758-1834 (Cambridge MA: Harvard University Press).

Tilly, C., Tilly, L. and Tilly, R. (1975) The Rebellious Century, 1830-1930 (Cambridge MA: Harvard University Press).

Uhr, J. (1998) Deliberative Democracy in Australia: The Changing Place of Parliament (Cambridge: Cambridge University Press).

Van Deth, J. W., Montero, J. R. and Westholm, A. (2007) Citizenship and Involvement in European Democracies. A Comparative Analysis (London: Routledge).

Verba, S., Schlozman, K. L. and Brady, H. E. (1995) Voice and Equality. Civic Voluntarism in American Politics (Harvard: Harvard University Press).

Wasserman, S. and Faust, K. (1994) Social Network Analysis: Methods and Applications (Cambridge: Cambridge University Press).

Wessler, H. (2008) 'Investigating deliberativeness comparatively', Political Communication, 25:1, 1-22.

Williams, M. (2000) Voice, Trust and Memory: Marginalized Groups and the Failings of Liberal Representation (Princeton NJ: Princeton University Press).

Young, I. (2000) Inclusion and Democracy (Oxford: Oxford University Press). 


\section{AUTHOR QUERY FORM}

Dear Author,

During the preparation of your manuscript for publication, the questions listed below have arisen. Please attend to these matters and return this form with your proof.

Many thanks for your assistance.

\begin{tabular}{|l|l|l|}
\hline $\begin{array}{l}\text { Query } \\
\text { References }\end{array}$ & \multicolumn{1}{|c|}{ Query } & Remarks \\
\hline 1 & $\begin{array}{l}\text { AUTHOR: Figure 3 is of poor quality [labels and } \\
\text { lines are blurry]. Please check required artwork } \\
\text { specifications at http://authorservices.wiley. } \\
\text { com/bauthor/illustration.asp }\end{array}$ & \\
\hline
\end{tabular}


Required software to e-Annotate PDFs: Adobe Acrobat Professional or Adobe Reader (version 8.0 or above). (Note that this document uses screenshots from Adobe Reader $\mathrm{X}$ )

The latest version of Acrobat Reader can be downloaded for free at: http://get.adobe.com/reader/

Once you have Acrobat Reader open on your computer, click on the Comment tab at the right of the toolbar:

닙

This will open up a panel down the right side of the document. The majority of tools you will use for annotating your proof will be in the Annotations section, pictured opposite. We've picked out some of these tools below:

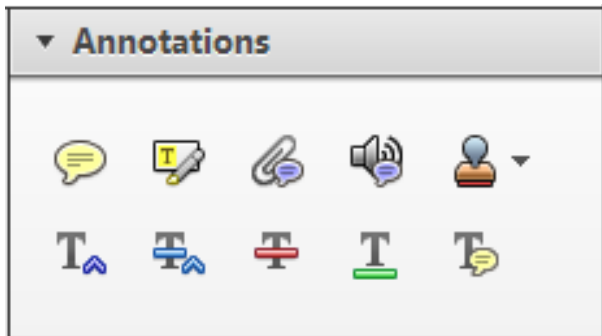

1. Replace (Ins) Tool - for replacing text.

Strikes a line through text and opens up a text box where replacement text can be entered.

\section{How to use it}

- Highlight a word or sentence.

- Click on the Replace (Ins) icon in the Annotations section.

- Type the replacement text into the blue box that appears.

Idard tramework for the analysis of $\mathrm{m}$ icy-Nevertheless, it also led to exog،

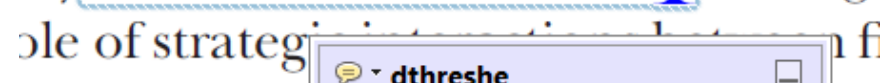
aber of comp 08/06/2011 15:58:17

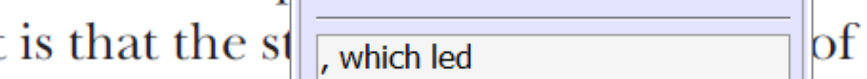
nain compo: be level, are exc nc

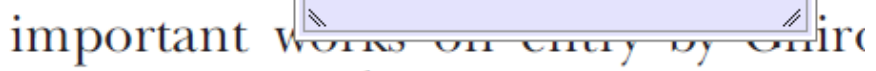
M heneferth) ${ }^{1}$ we anen the 'hlark $\mathrm{h}$

3. Add note to text Tool - for highlighting a section to be changed to bold or italic.

T Highlights text in yellow and opens up a text box where comments can be entered.

\section{How to use it}

- Highlight the relevant section of text.

- Click on the Add note to text icon in the Annotations section.

- Type instruction on what should be changed regarding the text into the yellow box that annears.

namic responses of mark ups ent with the VAR evidence

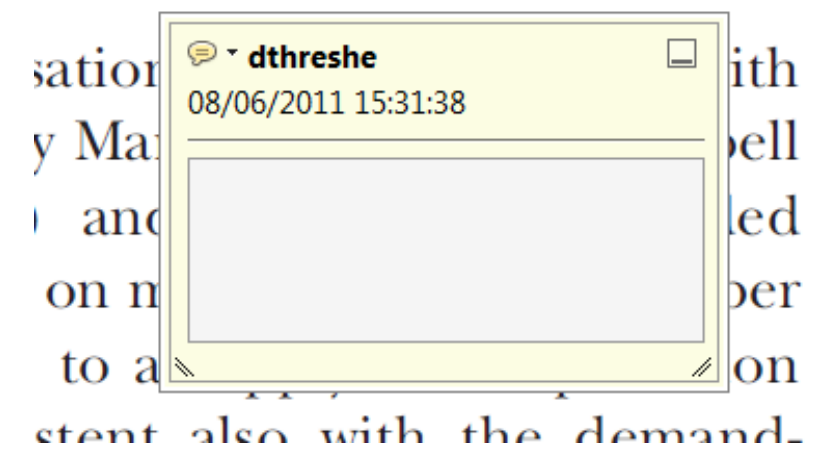

2. Strikethrough (Del) Tool - for deleting text.

Thikes a red line through text that is to be deleted.

\section{How to use it}

- Highlight a word or sentence.

- Click on the Strikethrough (Del) icon in the Annotations section.

there is no room tor extra prohts al c ups are zero and the number of ret) values are not determined by Blanchard and Kiyotaki (1987), rfect competition in general equilil ts of aggregate demand and supply lassical framework assuming monol eon an evorenois number of firms

\section{Add sticky note Tool - for making notes at} specific points in the text.

Marks a point in the proof where a comment needs to be highlighted.

\section{How to use it}

- Click on the Add sticky note icon in the Annotations section.

- Click at the point in the proof where the comment should be inserted.

- Type the comment into the yellow box that appears.

lallu allu suppiy silucks. hivst vi

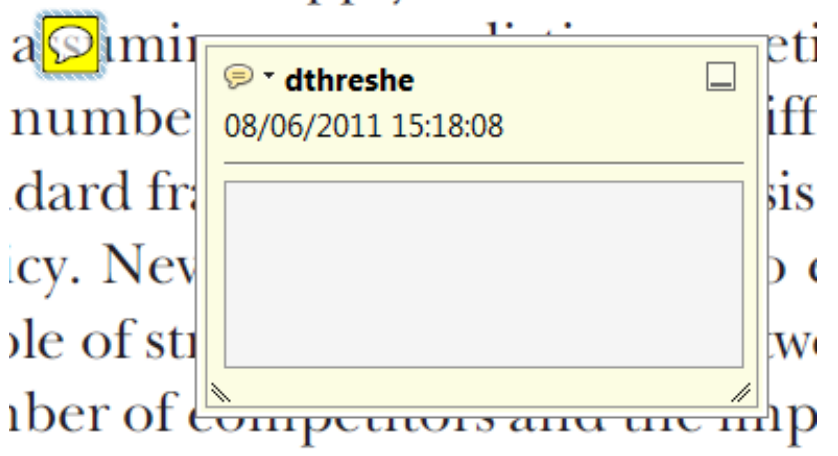

is that the structure of the secto 
5. Attach File Tool - for inserting large amounts of text or replacement figures.

Inserts an icon linking to the attached file in the appropriate pace in the text.

How to use it

- Click on the Attach File icon in the Annotations section.

- Click on the proof to where you'd like the attached file to be linked.

- Select the file to be attached from your computer or network.

- Select the colour and type of icon that will appear in the proof. Click OK.

E N D

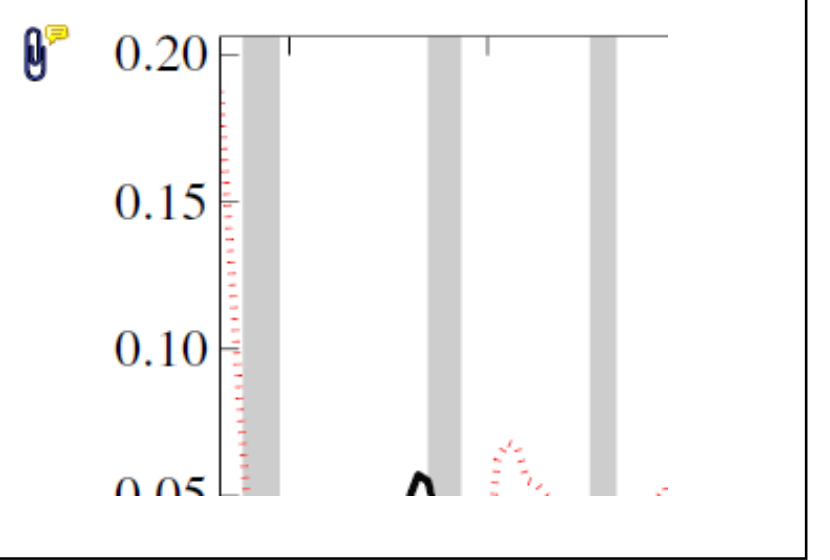

6. Add stamp Tool - for approving a proof if no corrections are required.

- Inserts a selected stamp onto an appropriate place in the proof

\section{How to use it}

- $\quad$ Click on the Add stamp icon in the Annotations section.

- $\quad$ Select the stamp you want to use. (The Approved stamp is usually available directly in the menu that appears).

- Click on the proof where you'd like the stamp to appear. (Where a proof is to be approved as it is, this would normally be on the first page).

of the Dusiness cycie, starting with the on perfect competition, constant ret

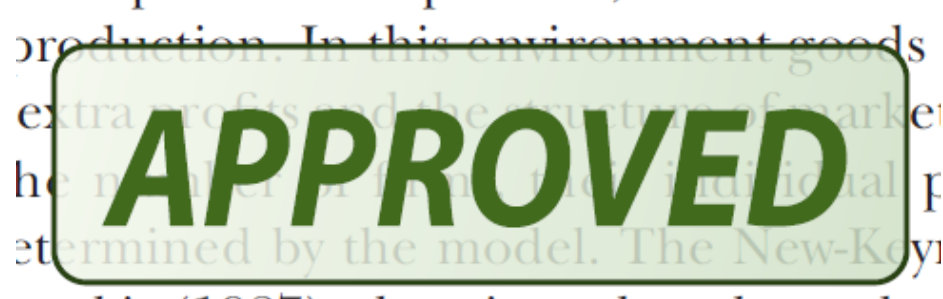

otaki (1987), has introduced produc general equilibrium models with nomin
- Drawing Markups

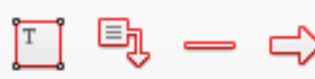

$0 \square \sqrt{6} D$

\section{How to use it}

- Click on one of the shapes in the Drawing Markups section.

- Click on the proof at the relevant point and draw the selected shape with the cursor.

- To add a comment to the drawn shape, move the cursor over the shape until an arrowhead appears.

- Double click on the shape and type any text in the red box that appears.
7. Drawing Markups Tools - for drawing shapes, lines and freeform annotations on proofs and commenting on these marks.

Allows shapes, lines and freeform annotations to be drawn on proofs and for comment to be made on these marks.

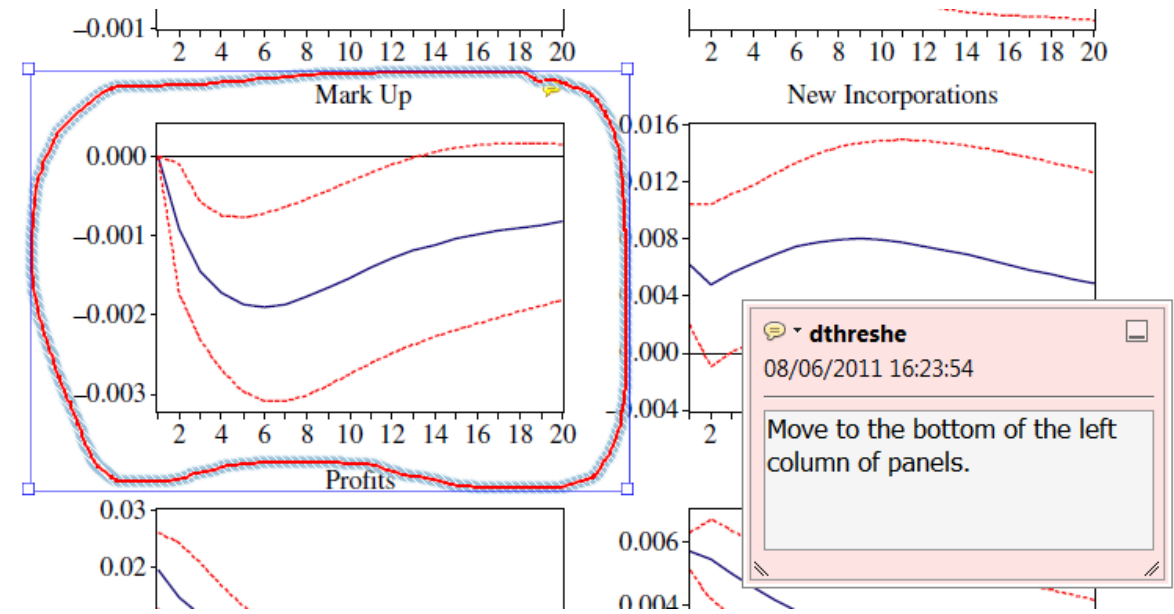

For further information on how to annotate proofs, click on the Help menu to reveal a list of further options:

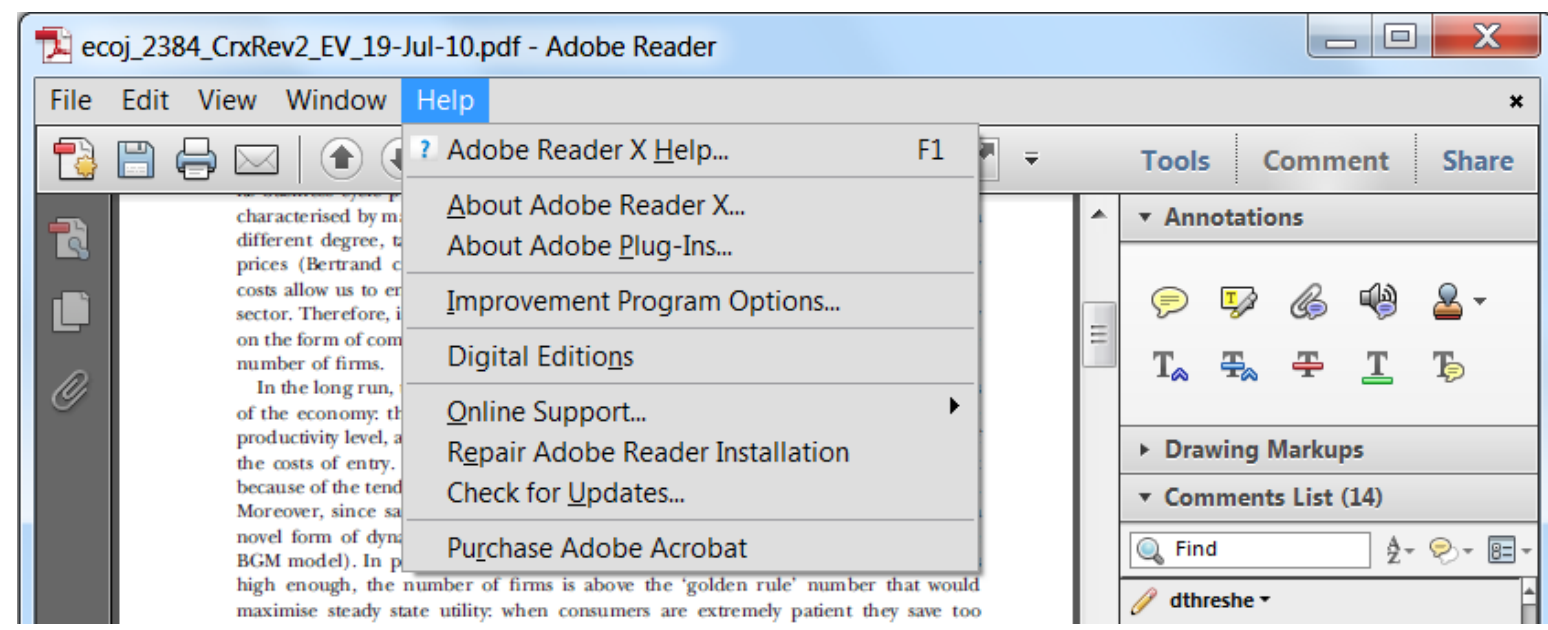

